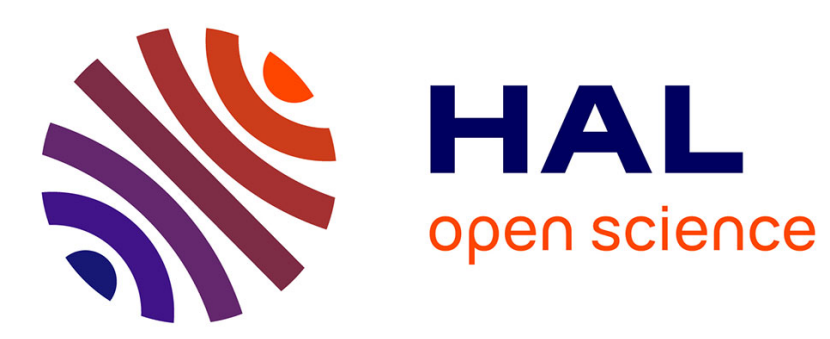

\title{
Commentary: Use of registries to investigate the past and develop the future.
}

Stefan James, Jean-Claude Daubert, Frans van de Werf

\section{To cite this version:}

Stefan James, Jean-Claude Daubert, Frans van de Werf. Commentary: Use of registries to investigate the past and develop the future.. BMJ, 2011, 342, pp.d3321. 10.1136/bmj.d2826 . hal-00907604

\section{HAL Id: hal-00907604 \\ https://hal.science/hal-00907604}

Submitted on 21 Nov 2013

HAL is a multi-disciplinary open access archive for the deposit and dissemination of scientific research documents, whether they are published or not. The documents may come from teaching and research institutions in France or abroad, or from public or private research centers.
L'archive ouverte pluridisciplinaire HAL, est destinée au dépôt et à la diffusion de documents scientifiques de niveau recherche, publiés ou non, émanant des établissements d'enseignement et de recherche français ou étrangers, des laboratoires publics ou privés. 


\title{
Commentary: Use of registries to investigate the past and develop the future
}

\author{
Stefan James associate professor ${ }^{1}$, Jean-Claude Daubert professor of cardiology ${ }^{2}$, Frans Van de \\ Werf professor ${ }^{3}$
}

${ }^{1}$ Uppsala Clinical Research Centre, Uppsala University, Uppsala, Sweden; ${ }^{2}$ University of Rennes 1 -CHU Rennes, France; ${ }^{3}$ Department of Cardiovascular Medicine, University Hospitals Leuven, Belgium

Ideally, collection of clinical data should be an integral part of healthcare systems. Without systematic collection of individual patient data and outcome it is impossible for individual doctors, healthcare providers, or regulatory agencies to understand how, when, and to whom healthcare is provided and the actual outcome of specific procedures or devices. Furthermore, complications of new devices or strategies, particularly those that are unexpected or infrequent, may be impossible to identify without systematic data collection in a registry.

As well as complications, a registry can identify and limit use of new treatments outside that for which they were clinically approved. For example, drug eluting stents were primarily used for off label indications during 2005-6. New treatments may also be underused because of financial barriers, insufficient training, or lack of confidence among doctors. A continuous registry may be able to identify such underuse and provide arguments for additional resources or more training .

Registries should always aim for consecutive enrolment of patients from a large geographical area, preferably nationwide. Selective enrolment will confound the data and limit the ability to describe the patient population of interest. Included data variables need to be adapted to a common standard such as the European Society of Cardiology's cardiology audit and registration data standards for interventional cardiology.

Registries should ideally be driven by the profession with close contact with local physicians to ensure high quality of the data input. This model has proved successful in the SWEDEHEART registry of coronary and valvular interventions ${ }^{1}$ in Sweden and MINAP, a registry of patients admitted to hospital with acute coronary syndromes in England and Wales. ${ }^{2}$ Sweden's registry captures $100 \%$ of patients having catheterisation or percutaneous coronary intervention, and data are accurate. Participation at the local level should be stimulated by providing online automated reports and options to assess performance against guidelines or national standards. National data should be automatically exported to a European registry. The data should be available to a steering committee that decides who can get access and under what circumstances.

\section{Opportunities and limitations of registries}

Clinical evidence should primarily be based on results of appropriately designed randomised clinical trials. However, their results are often limited by including selected populations, and they are expensive and cumbersome to perform.

Furthermore, for many subsets of patients randomised trials will never be (and can never be) performed. In this case observational studies are often the only option.

Retrospective analyses of prospectively collected registry data are inexpensive - the only costs relate to the analyses - and reflect the true clinical situation. They are ideal for descriptive studies and for outcome analyses but have limited value for comparisons between therapeutic options. Nevertheless, registries can be used as a platform for randomisation and thus allow large scale studies to be done at low cost. For example, the Swedish Coronary Angiography and Angioplasty Registry (SCAAR) is being used to prospectively evaluate mortality in patients given manual thrombus aspiration before primary percutaneous coronary intervention compared with that in patients given no aspiration. ${ }^{3}$

\section{Postmarketing surveillance}

Registries also have great potential for postmarketing surveillance. In Europe devices receive approval for use and CE marking from notified bodies and national competent authorities based on limited clinical documentation. Reports of problems with devices should be submitted to notified bodies, but it has been estimated that voluntary reporting may capture less than $10 \%$ of relevant events. We recommend that approval for commercial use of devices without adequate clinical data should be conditional on rigorous postmarketing surveillance studies to prove safety and efficacy in broad populations. ${ }^{4}$ It is the manufacturer's responsibility to monitor the performance of their devices, for as long as they are in use, and to ensure these devices continue to be safe and suitable for clinical use. It is also important that the European database on medical devices (EUDAMED) should be in the public domain. 
Although all countries are required to submit safety data-including CE certification, clinical data, and device failures - to the database from this month, the information will be available only to marketing surveillance authorities.

Large scale postmarketing studies are costly, require specially designed web based clinical report forms, and are often funded and driven by industry. Instead postmarketing studies should be done within existing large registries developed by professional organisations. This will ensure broad unselected populations and avoid competition between randomised trials and registries. It would also stimulate input from academia and support the development of large continuous quality registries. When licensing authorities request postmarketing surveillance studies, the manufacturers should have to provide financial support to the registry.

Competing interests: All authors have completed the Unified Competing Interest form at www.icmje.org/coi_disclosure.pdf (available on request from the corresponding author) and declare no support from any organisation for the submitted work; no financial relationships with any organisation that might have an interest in the submitted work in the previous three years; and no other relationships or activities that could appear to have influenced the submitted work.

Provenance and peer review: Commissioned; not externally peer reviewed

1 Jernberg T, Attebring MF, Hambraeus K, Ivert T, James S, Jeppsson A, et al. The Swedis web-system for enhancement and development of evidence-based care in heart disease evaluated according to recommended therapies (SWEDEHEART). Heart 2010;96:1617-21. 2 Herrett E, Smeeth L, Walker L, Weston W, MINAP Academic Group. The Myocardial Ischaemia National Audit Project (MINAP). Heart 2010;96:1264-7.

3 Frobert O, Lagerqvist B, Gudnason T, Thuesen L, Svensson R, Olivecrona GK, et al. Thrombus aspiration in ST-elevation myocardial infarction in Scandinavia (TASTE trial). A multicenter, prospective, randomized, controlled clinical registry trial based on the Swedish angiography and angioplasty registry (SCAAR) platform. Study design and rationale. Am Heart J 2010;160:1042-8.

4 Fraser AG, Daubert JC, Van de Werf F, Estes NA, Smith SC Jr, Krucoff MW, et al. Clinical evaluation of cardiovascular devices-principles, problems, and proposals for European regulatory reform. Eur Heart J 2011 http://eurhearti.oxfordjournals.org/cgi/reprint/ehr171.

Cite this as: $B M J 2011 ; 342: \mathrm{d} 2826$ 